\title{
The correlation between temperament and adherence for HIV and TB patients
}

\author{
Daniela-Ica Biriş ${ }^{1 *}$, Teodora Moisil ${ }^{1}$, Elena-Voichița Lăzureanu² \\ From The 9th Edition of the Scientific Days of the National Institute for Infectious Diseases Prof Dr Matei Bals \\ Bucharest, Romania. 23-25 October 2013
}

\section{Background}

The patient's temperament plays an important role in the success or failure of any treatment. The temperament is the dynamic-energy dimension of the personality which is mostly seen in the demeanor. On the other hand the adherence is the correlation between the patient's behavior and the medical recommendation adapted to the patient needs. Non-adherence to treatment and the factor that influences it is a continuous concern and for this reason we launched the hypothesis: "Does the behavior have an influence on the adherence of patients suffering from HIV and TB infection?"

\section{Methods}

The comparative study was performed on a sample of 60 patients: 30 patients with HIV (15 new cases and 15 experienced) and 30 patients with TB (15 new cases and 15 with recurrence). We applied three questionnaires: the Heymans temperamental questionnaire, the questionnaire for evaluating the adherence for antiretroviral treatment and the questionnaire for evaluating the adherence for the antituberculous treatment.

\section{Results}

The results show a significant non-adherence of the patients with a phlegmatic, choleric or passionate temperament, these results being confirmed both in the HIV and TB patients.

\section{Conclusion}

Being aware of the temperament of the HIV and TB patients can eliminate one of the unknown barriers of non-adherence by a cautious observation. The patients

\footnotetext{
* Correspondence: danabiris70@yahoo.com

${ }^{1}$ Dr. Victor Babeş Clinical Hospital of Infectious Diseases and Pneumology, Timişoara, Romania
}

Full list of author information is available at the end of the article with a phlegmatic, choleric or passionate temperament are more predisposed to non-adherence. From a psychological point of view, we can agree that the temperament has an influence over the adherence.

\section{Authors' details}

${ }^{1}$ Dr. Victor Babeş Clinical Hospital of Infectious Diseases and Pneumology, Timişoara, Romania. "University of Medicine and Pharmacy "Victor Babeş" Timişoara, Rom®nia.

Published: 16 December 2013

doi:10.1186/1471-2334-13-S1-P107

Cite this article as: Biriş et al:: The correlation between temperament and adherence for HIV and TB patients. BMC Infectious Diseases 2013 13(Suppl 1):P107.
Submit your next manuscript to BioMed Central and take full advantage of:

- Convenient online submission

- Thorough peer review

- No space constraints or color figure charges

- Immediate publication on acceptance

- Inclusion in PubMed, CAS, Scopus and Google Scholar

- Research which is freely available for redistribution

Submit your manuscript at www.biomedcentral.com/submit
() Biomed Central
C Biomed Central

(c) 2013 Biriş et al; licensee BioMed Central Ltd. This is an Open Access article distributed under the terms of the Creative Commons Attribution License (http://creativecommons.org/licenses/by/2.0), which permits unrestricted use, distribution, and reproduction in any medium, provided the original work is properly cited. 